\title{
Matrix metalloproteinase-3 gene promoter polymorphisms: A potential risk factor for pelvic organ prolapse
}

\author{
CHARALAMPOS KARACHALIOS ${ }^{1}$, PANAGIOTIS BAKAS ${ }^{1}$, GEORGIOS KAPAROS ${ }^{2}$, \\ STYLIANI DEMERIDOU ${ }^{2}$, ILIAS LIAPIS ${ }^{1}$, CHARALAMPOS GRIGORIADIS ${ }^{1}$ and AGGELOS LIAPIS ${ }^{1}$ \\ ${ }^{1}$ Second Department of Obstetrics and Gynecology; ${ }^{2}$ Department of Biopathology, Aretaieio University \\ Hospital, National and Kapodistrian University of Athens, Medical School, Athens 11528, Greece
}

Received June 13, 2016; Accepted July 13, 2016

DOI: $10.3892 / b r .2016 .736$

\begin{abstract}
Pelvic organ prolapse (POP) is a common multifactorial condition. Matrix metalloproteinases (MMPs) are enzymes capable of breaking down various connective tissue elements. Single-nucleotide polymorphisms (SNPs) in regulatory areas of MMP-encoding genes can alter their transcription rate, and therefore the possible effect on pelvic floor supporting structures. The insertion of an adenine (A) base in the promoter of the $M M P-3$ gene at position $-1612 /-1617$ produces a sequence of six adenines (6A), whereas the other allele has five (5A). The aim of the present study was to investigate the possible association of MMP-3 gene promoter SNPs with the risk of POP. The patient group comprised 80 women with clinically significant POP [Stage II, III or IV; POP quantification (POP-Q) system]. The control group consisted of 80 females without any or important pelvic floor support defects (Stages 0 or I; POP-Q system). All the participants underwent the same preoperative evaluation. SNP detection was determined with whole blood sample DNA analysis by quantitative polymerase chain reaction (PCR) in LightCycler ${ }^{\circledR}$ PCR platforms, using the technique of sequence-specific hybridization probe-binding assays and melting temperature curve analysis. The results showed there was no statistically significant difference between $5 \mathrm{~A} / 5 \mathrm{~A}$, 5A/6A and 6A/6A $M M P-3$ gene promoter variants in the two study groups $(\mathrm{P}=0.4758)$. Therefore, $M M P-3$ gene promoter SNPs alone is insufficient to increase the genetic susceptibility to POP development.
\end{abstract}

Correspondence to: Dr Charalampos Karachalios, Second Department of Obstetrics and Gynecology, Aretaieio University Hospital, National and Kapodistrian University of Athens, Medical School, 76 Vassilissis Sofias Avenue, Athens 11528, Greece

E-mail: harrykarachalios@windowslive.com

Abbreviations: POP, pelvic organ prolapse; MMP, matrix metalloproteinase; SNP, single-nucleotide polymorphism; A, adenine; POP-Q, pelvic organ prolapse quantification system; $\mathrm{PCR}$, polymerase chain reaction

Key words: gene, MMP-3, polymorphisms, prolapse

\section{Introduction}

Pelvic organ prolapse (POP) is an extremely common condition affecting numerous females worldwide. According to data from the Women's Health Initiative, its prevalence in the general population was estimated at $41 \%$ (1). The etiopathogenesis of POP is complicated. There are several recognized risk factors responsible for the gradual development of POP, including age, hormonal status, previous surgical operations of the pelvis and abdomen, obstetric trauma, race, family history, chronic constipation and obesity (2-9). However, the exact pathophysiological pathways involved in this entity remain to be clarified. Connective tissue metabolism disorders may affect the supporting structures of the pelvic organs (e.g., ligaments) and have also been described as potential causes of POP (10).

Matrix metalloproteinases (MMPs) are a family of catabolic enzymes capable of breaking down collagen and other components of the extracellular matrix. Therefore, they can contribute to change of the clinical expression of a variety of diseases, such as breast cancer, ovarian neoplasms and pulmonary fibrosis (11-14). MMP-3 (alternatively known as stromelysin-1) is important in connective tissue remodeling. It primarily degrades collagen types II, III and IV (15), but also exerts a catabolic effect on other collagen types, elastin, gelatin and fibronectin (16). In addition, stromelysin-1 can induce the action of other MMPs (17). Therefore, MMP-3 is involved in various disorders, such as chronic heart failure, rheumatoid arthritis and abdominal aortic aneurysms (18-20).

Single-nucleotide polymorphisms (SNPs) are genetic sequence variations that can modify the expression of a gene when they occur in its regulatory areas, such as the gene's promoter (21). The gene that encodes the transcription of MMP-3 is located in position 11q22.3 (22). Insertion of an adenine (A) deoxyribonucleotide in the promoter of $M M P-3$ gene at position -1612/-1617 upstream from the beginning of the transcription frame produces a sequence of six consecutive adenines (6A), while the other allele has only five (5A). The expression of the $6 \mathrm{~A}$ variant promotes the connection of the repressor ZBP-89 with the $M M P-3$ gene, whose expression is, thus, downregulated. As a result, there are three possible genotypes for each woman: 5A/5A, 5A/6A and 6A/6A (23). 
A study by Skorupski et al (24) showed that the higher MMP-3 transcription rate in 5A/5A Polish females could induce a more rapid breakdown of the extracellular matrix and, consecutively, the clinical appearance of POP. The above authors concluded that certain SNPs of MMP-3 alone cannot increase the risk of POP and that only the $5 \mathrm{~A} / 5 \mathrm{~A}$ and $5 \mathrm{~A} / 6 \mathrm{~A}$ MMP-3 polymorphisms combined with a similar SNP for MMP-1 seem to increase a woman's possibility of developing POP. The aim of the present study was to investigate the association of $M M P-3$ gene promoter SNPs alone with the risk of POP. The results showed there was no statistically significant difference between $5 \mathrm{~A} / 5 \mathrm{~A}, 5 \mathrm{~A} / 6 \mathrm{~A}$ and $6 \mathrm{~A} / 6 \mathrm{~A} M M P-3$ gene promoter variants in the two study groups.

\section{Materials and methods}

Sample selection. Approval for the study (ref. no. M-127/29-03-2012) was obtained from the Institutional Ethics Committee of the National and Kapodistrian University of Athens, Medical School (Athens, Greece). The study involved 160 Caucasian women, recruited between September 27, 2012 and February 24, 2014. These women were divided into the study and control groups ( $\mathrm{n}=80$ each). All 160 women provided written informed consent. The participants were referred from the Institutional Outpatient Urogynecology Unit and from the Institutional Gynecology Outpatient Clinic and were asked to participate in the present study following admission to the respective hospitals. The study group comprised 80 women with symptomatic POP [Stages II, III or IV; POP quantification (POP-Q) system] (25). The 80 patients underwent pelvic reconstructive surgical procedures the day after their participation in the study. The control group included 80 women without significant support defects (Stages 0 or I; POP-Q system). All 80 women included in the control group underwent total abdominal hysterectomy, mainly for symptoms related to the presence of uterine myomas, such as pelvic pain. The control group (the women who underwent total abdominal hysterectomy for reasons different from uterine myomas) had their uterus removed for a variety of etiologies, such as chronic repetitive dysfunctional uterine bleeding. No statistical difference $(\mathrm{P}>0.05)$ was observed between the two groups with regard to parameters including age, body mass index (BMI), positive family history for POP, past pelvic and/or abdominal operations, gravidity, parity, number of live births, neonatal weights, delivery modes, obstetric injuries, manual profession, smoking, chronic cough, chronic constipation, and age of menopause $(2-5,7,8,26)$. The severity of the participants' pelvic organ prolapse was assessed during their preoperative evaluation, together with obtaining an extensive medical, surgical, gynecologic and obstetric history. Additionally, each woman underwent the same diagnostic routine, which involved measurement of the parameters mentioned below with the use of the appropriate electronic devices: systolic and diastolic blood pressure via upper arm digital sphygmomanometer (BP A100 Plus; Microlife AG, Widnau, Switzerland), heart and respiratory rate, oxygen saturation via pulse oximetry, axillary temperature (Tm), height and body mass for BMI calculation, general physical examination, bimanual pelvic examination with POP-Q grade evaluation and routine biochemical tests from venous whole
Table I. Preparations and settings for the polymerase chain reaction.

\begin{tabular}{lc}
\hline $\begin{array}{l}\text { Preparation of } \\
\text { the reaction mix }\end{array}$ & $\begin{array}{c}\text { Instrument } \\
\text { settings }\end{array}$ \\
\hline $\begin{array}{l}\text { Reaction mixture: } 20 \mu 1 \\
\mathrm{H}_{2} \mathrm{O}: 10.4-14.4 \mu 1\end{array}$ & $\begin{array}{c}\text { LightCycler }^{\circledR} 480 \text { Instrument } \\
\text { Reagent mix: } 1 \mu 1\end{array}$ \\
$\begin{array}{l}\text { BastStart DNA Master }{ }^{\text {a: }}: 2 \mu 1 \\
\text { Detection format: Simple probe }\end{array}$ \\
$\begin{array}{l}\mathrm{MgCl}_{2}(25 \mathrm{mM}): 1.6 \mu 1 \\
\text { DNA: } 1-5 \mu 1(\sim 50 \mathrm{ng})\end{array}$ \\
$\begin{array}{l}\text { Final } \mathrm{MgCl}_{2} \\
\text { concentration: } 3 \mathrm{mM}\end{array}$ & LightCycler $^{\circledR} 480$ \\
\hline
\end{tabular}

${ }^{\text {aLightCycler }}{ }^{\circledR}$ FastStart DNA Master HybProbe (Roche Diagnostics $\mathrm{GmbH})$.

blood samples. Any subjects with malignant neoplasms, autoimmune disorders, chronic inflammatory conditions (e.g., rheumatoid arthritis and ulcerative colitis), joint and bone diseases and any other life-threatening or serious disturbances were excluded from the study, as the levels of MMP-3 expression in their body may be attributed to one of the aforementioned conditions and, therefore, alter the effect of POP alone on the basis of MMP-3 levels $(19,27)$. Each woman was characterized by an Arabic number (from 1 to 80 ) and capital letter 'A' (study group) or 'B' (control group).

Laboratory analysis of blood samples. After signing the informed consent form, $5 \mathrm{ml}$ of whole venous blood were drawn from the median cubital vein of the participants $16 \mathrm{~h}$ prior to surgery and collected into $10 \mathrm{ml}$ large tubes with K2-EDTA spray-dried anticoagulant. Each sample tube was clearly labeled with the appropriate number-letter combination that characterized each woman. Only the first author (C.K.) was aware of the exact number-letter combination for each subject. Immediately after drainage, the blood samples were quickly transferred to the Molecular Biopathology Unit of the Institutional Biopathology Department, which is located at the basement of the building where the participants were hospitalized. The third and fourth authors (G.K. and S.D.) carried out the sample analysis. Nucleic DNA was extracted from white blood cells with the aid of a special kit (High Pure ${ }^{\circledR}$ PCR Template Preparation kit; Roche Diagnostics GmbH, Mannheim, Germany) and stored without other biomaterials in a special refrigerator at $-20^{\circ} \mathrm{C}$ until further use.

The MMP-3 gene promoter variants were determined using hot-start quantitative polymerase chain reaction (qPCR) in LightCycler ${ }^{\circledR}$ PCR platforms, using the technique of sequence-specific hybridization probe binding assays. LightSNiP ${ }^{\circledR}$ assays (TIB MOLBIOL GmbH, Berlin, Germany) and LightCycler ${ }^{\circledR}$ FastStart DNA Master HybProbe (Roche Diagnostics $\mathrm{GmbH}$ ) were used for the reaction. The former is a special mixture of primers and fluorescent probes (primer 1, primer 2, 3'-FL HybProbe and 5'-LC HybProbe), 
Table II. Programming parameters for the LightCycler ${ }^{\circledR} 480$ Instrument.

Cycling (quantification)
Melting

\begin{tabular}{llll} 
Segment 1 & Segment 2 & Segment 3 & Cooling \\
\hline
\end{tabular}

Parameter

Denaturation Segment 1 Segment 2 Segment 3

$\begin{array}{cccc}1 & 1 & 1 & 1 \\ 95 & 40 & 75 & 40 \\ 30 \mathrm{sec} & 2 \mathrm{~min} & 0 & 30 \mathrm{sec} \\ 4.6 & 2 & - & 2\end{array}$

No. of cycles

Target $\left({ }^{\circ} \mathrm{C}\right)$

Hold

Ramp rate $\left({ }^{\circ} \mathrm{C} / \mathrm{sec}\right)$,

384-wells

Ramp rate $\left({ }^{\circ} \mathrm{C} / \mathrm{sec}\right)$,

96-wells

Acquisition mode

Acquisitions (per ${ }^{\circ} \mathrm{C}$ )

45
60
$10 \mathrm{sec}$

45

72

$10 \mathrm{~min}$

4.6

4.4

None
95

4.6

4.4

None
2.4

2.2

$15 \mathrm{sec}$

4.6

Single
4.4

4.4

None
None
1.5

-

1.5
2

c

which is used for the identification of point mutations, such as SNPs, provided that the reference SNP ID number ( $\mathrm{rs}$ ) of the SNP is known. The rs for the insertion of an adenine (A) deoxyribonucleotide in the promoter of the $M M P-3$ gene at position -1612/-1617, upstream from the beginning of the transcription frame was 3025058 (28). The latter was a hot-start reaction mix for sensitive PCR applications in LightCycler ${ }^{\circledR}$ capillaries, using HybProbe probes as a detection format. It is a master mix for performing SNP detection. This kit contains all necessary reagents [LightCycler ${ }^{\circledR}$ FastStart enzyme, LightCycler ${ }^{\circledR}$ FastStart reaction mix HybProbe, $\mathrm{MgCl}_{2}$ stock solution $(25 \mathrm{mM})$ and water (PCR grade)]. However, the exact sequences of primers and exact sequences of the probes was unavailable, due to patent and marketing policies of TIB MOLBIOL GmbH. Further technical details for the preparation of PCR are provided in Tables I and II. Determination of each woman's genotype was based on the fact that each DNA fragment's melting Tm was specific for only one of the MMP-3 gene promoter variants (Fig. 1). As a result, $5 \mathrm{~A} / 5 \mathrm{~A}$ women had a slightly higher melting Tm peak than the $6 \mathrm{~A} / 6 \mathrm{~A}$ women, while heterozygotes $(5 \mathrm{~A} / 6 \mathrm{~A})$ had a bimodal (i.e., with two peaks) melting Tm curve.

Statistical analysis. The statistical analysis of the sample's various parameters which were possibly associated with prolapse was carried out by GraphPad Prism ${ }^{\circledR}$ v.7 and GraphPad InStat ${ }^{\circledR}$ v.3 (GraphPad Software Inc ${ }^{\mathrm{TM}}$, San Diego, CA, USA). The comparison of the various allele frequencies between patients and control subjects was performed using the Chi-square test for independence in a $3 \times 2$ contingency table. The quantitative variables of the present study, including age, number of past surgical operations in the pelvis and/or abdomen per female, gravidity, parity, live births, neonatal weights, normal deliveries, operative vaginal deliveries, cesarean sections, and menopause age, did not follow the Gaussian distribution, because either one or both groups failed to pass the Kolmogorov-Smirnov normality test. Therefore, the non-parametric Mann-Whitney U test was used for the differences of means and medians. The possible statistical significance between the remaining (categorical) variables, including obesity, positive family history for POP, obstetric injuries, manual profession, smoking, chronic constipation

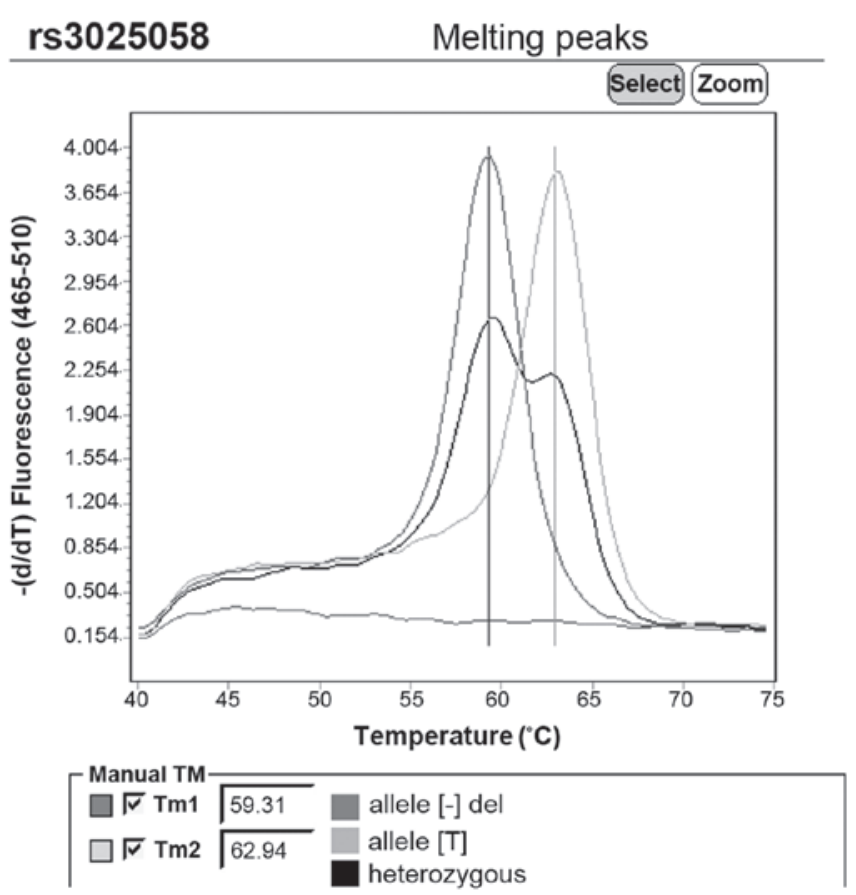

Figure 1. Melting temperature ( $\mathrm{Tm})$ peak curve analysis.

and chronic cough, and POP was tested using the Chi-square test (Tables III and IV). The level of significance was set to $\mathrm{P}<0.05$.

\section{Results}

Clinical characteristics of patients and controls. Tables III and IV show many clinical characteristics of the study and control group women and provide a concise review of the relevant statistical analysis. There was no statistically significant difference between the two groups with regard to age, BMI, positive family history for POP, past pelvic and/or abdominal operations, gravidity, parity, number of live births, neonatal weights, delivery modes, obstetric injuries, manual profession, smoking, chronic cough, chronic constipation, and age of menopause $(\mathrm{P}>0.05)$. This result was expected, because group B women were frequency-matched to group A women 
Table III. Characteristics and statistics of the study and control groups.

\begin{tabular}{|c|c|c|c|c|}
\hline Variables & Control group & Study group & Total & Statistics \\
\hline No. of patients & 80 & 80 & 160 & \\
\hline \multicolumn{5}{|l|}{ Age (years) } \\
\hline Mean & 64.53 & 63.23 & & $\mathrm{P}=0.23$ \\
\hline $\mathrm{SD}$ & 8.85 & 10.95 & & \\
\hline $95 \% \mathrm{CI}$ & $62.55-66.5$ & $60.78-65.67$ & & \\
\hline Min-max (median) & $35-80(65)$ & $43-89(63)$ & & \\
\hline \multicolumn{5}{|l|}{ BMI, n (\%) } \\
\hline$<30 \mathrm{~kg} / \mathrm{m}^{2}$ & $55(34)$ & $57(36)$ & $112(70)$ & \\
\hline$\geq 30 \mathrm{~kg} / \mathrm{m}^{2}$ & $25(16)$ & $23(14)$ & $48(30)$ & \\
\hline Total & $80(50)$ & $80(50)$ & $160(100)$ & $\mathrm{P}=0.86$ \\
\hline Odds ratio $(95 \% \mathrm{CI})$ & & & & $1.17(0.57-2.22)$ \\
\hline \multicolumn{5}{|l|}{ Positive family history } \\
\hline Yes & $34(21)$ & $46(29)$ & $80(50)$ & \\
\hline No & $28(18)$ & $52(32)$ & $80(50)$ & \\
\hline Total & $62(39)$ & $98(61)$ & $160(100)$ & $\mathrm{P}=0.42$ \\
\hline Odds ratio $(95 \% \mathrm{CI})$ & & & & $1.37(0.72-2.6)$ \\
\hline \multicolumn{5}{|c|}{ Past pelvic and/or abdominal surgery } \\
\hline Mean & 0.84 & 0.9 & & $\mathrm{P}=0.24$ \\
\hline $\mathrm{SD}$ & 0.67 & 1.36 & & \\
\hline No. & 67 & 72 & 139 & \\
\hline $95 \% \mathrm{CI}$ & $0.69-0.99$ & $0.6-1.2$ & & \\
\hline Min-max (median) & $0-3(1)$ & $0-8(1)$ & & \\
\hline \multicolumn{5}{|l|}{ Gravidity } \\
\hline Mean & 2.11 & 1.83 & & $\mathrm{P}=0.08$ \\
\hline $\mathrm{SD}$ & 1.01 & 1.01 & & \\
\hline No. & 169 & 146 & 315 & \\
\hline $95 \% \mathrm{CI}$ & $1.89-2.34$ & $1.59-2.07$ & & \\
\hline Min-max (median) & $0-5(2)$ & $0-5(2)$ & & \\
\hline \multicolumn{5}{|l|}{ Parity } \\
\hline Mean & 2.09 & 1.9 & & $\mathrm{P}=0.14$ \\
\hline $\mathrm{SD}$ & 0.79 & 0.06 & & \\
\hline No. & 159 & 131 & 290 & \\
\hline $95 \% \mathrm{CI}$ & $1.91-2.27$ & $1.75-2.04$ & & \\
\hline Min-max (median) & $1-4(2)$ & $1-3(2)$ & & \\
\hline \multicolumn{5}{|l|}{ Live births } \\
\hline Mean & 2.11 & 1.87 & & $\mathrm{P}=0.1$ \\
\hline $\mathrm{SD}$ & 1 & 0.64 & & \\
\hline No. & 158 & 131 & 289 & \\
\hline $95 \% \mathrm{CI}$ & $1.89-2.34$ & $1.72-2.02$ & & \\
\hline Min-max (median) & $0-5(2)$ & $0-3(2)$ & & \\
\hline \multicolumn{5}{|l|}{ Neonatal weights (kg) } \\
\hline Mean & $3,373.06$ & $3,331.15$ & & $\mathrm{P}=0.35$ \\
\hline SD & 350.24 & 413.4 & & \\
\hline No. & 158 & 131 & 289 & \\
\hline $95 \% \mathrm{CI}$ & $3,318.3-3,427.8$ & $3,260.3-3,401.9$ & & \\
\hline Min-max (median) & $1,400-4,300(3,400)$ & $1,600-4,980(3,350)$ & & \\
\hline
\end{tabular}

$\mathrm{SD}$, standard deviation; CI, confidence interval.

on the above factors, which are generally regarded as predisposing to POP.
MMP-3 gene promoter variants. The blood samples were successfully analyzed for the -1612/-1617 MMP-3 gene 
Table IV. Characteristics and statistics of the study and control groups.

\begin{tabular}{|c|c|c|c|c|}
\hline Variables & Control group & Study group & Total & Statistics \\
\hline \multicolumn{5}{|l|}{ Normal deliveries } \\
\hline Mean & 1.76 & 1.49 & & $\mathrm{P}=0.09$ \\
\hline SD & 1 & 0.8 & & \\
\hline No. & 134 & 103 & 237 & \\
\hline $95 \% \mathrm{CI}$ & $1.54-1.99$ & $1.29-1.69$ & & \\
\hline Min-max (median) & $0-4(2)$ & $0-3(2)$ & & \\
\hline \multicolumn{5}{|c|}{ Operative vaginal deliveries } \\
\hline Mean & 0.18 & 0.06 & & $\mathrm{P}=0.05$ \\
\hline $\mathrm{SD}$ & 0.45 & 0.24 & & \\
\hline No. & 14 & 4 & 18 & \\
\hline $95 \% \mathrm{CI}$ & $0.08-0.29$ & $0-0.11$ & & \\
\hline Min-max (median) & $0-2(0)$ & $0-1(0)$ & & \\
\hline \multicolumn{5}{|l|}{ Cesarean sections } \\
\hline Mean & 0.14 & 0.32 & & $\mathrm{P}=0.36$ \\
\hline $\mathrm{SD}$ & 0.39 & 0.76 & & \\
\hline No. & 11 & 22 & 33 & \\
\hline $95 \% \mathrm{CI}$ & $0.06-0.23$ & $0.14-0.5$ & & \\
\hline Min-max (median) & $0-2(0)$ & $0-3(0)$ & & \\
\hline \multicolumn{5}{|l|}{ Obstetric injuries } \\
\hline Mean & 0.09 & 0.09 & & $\mathrm{P}=0.12$ \\
\hline $\mathrm{SD}$ & 0.29 & 0.17 & & \\
\hline No. & 7 & 2 & 9 & \\
\hline $95 \% \mathrm{CI}$ & $0.03-0.16$ & $0-0.07$ & & \\
\hline Min-max (median) & $0-1(0)$ & $0-1(0)$ & & \\
\hline \multicolumn{5}{|c|}{ Manual profession, n (\%) } \\
\hline Yes & $27(17)$ & $16(10)$ & $43(27)$ & \\
\hline No & $53(33)$ & $64(40)$ & $117(73)$ & \\
\hline Total & $80(50)$ & $80(50)$ & $160(100)$ & $\mathrm{P}=0.07$ \\
\hline OR $(95 \% \mathrm{CI})$ & & & $2.04(0.99-4.18)$ & \\
\hline \multicolumn{5}{|l|}{ Smoking, n (\%) } \\
\hline Yes & $27(17)$ & $23(14)$ & $50(31)$ & \\
\hline No & $53(33)$ & $57(36)$ & $110(69)$ & \\
\hline Total & $80(50)$ & $80(50)$ & $160(100)$ & $\mathrm{P}=0.61$ \\
\hline OR $(95 \% \mathrm{CI})$ & & & $1.26(0.65-2.47)$ & \\
\hline \multicolumn{5}{|l|}{ Chronic cough, n (\%) } \\
\hline Yes & $28(18)$ & $17(11)$ & $45(28)$ & \\
\hline No & $52(33)$ & $63(39)$ & $115(72)$ & \\
\hline Total & $80(50)$ & $80(50)$ & $160(100)$ & $\mathrm{P}=0.08$ \\
\hline OR $(95 \% \mathrm{CI})$ & & & $2(0.99-4.04)$ & \\
\hline \multicolumn{5}{|c|}{ Chronic constipation, n (\%) } \\
\hline Yes & $27(17)$ & $18(11)$ & $45(28)$ & \\
\hline No & $53(33)$ & $62(39)$ & $115(72)$ & \\
\hline Total & $80(50)$ & $80(50)$ & $160(100)$ & $\mathrm{P}=0.16$ \\
\hline OR $(95 \% \mathrm{CI})$ & & & $1.76(0.87-3.54)$ & \\
\hline \multicolumn{5}{|c|}{ Menopause age (years) } \\
\hline Mean & 49.9 & 50.19 & & $\mathrm{P}=0.54$ \\
\hline $\mathrm{SD}$ & 3.31 & 2.84 & & \\
\hline No. & 80 & 80 & 160 & \\
\hline $95 \% \mathrm{CI}$ & $49.16-50.64$ & $49.56-50.82$ & & \\
\hline Min-max (median) & $35-56(50)$ & $39-57(50)$ & & \\
\hline
\end{tabular}

SD, standard deviation; CI, confidence interval. 
Table V. Matrix metalloproteinase-3 (MMP-3) gene promoter single-nucleotide polymorphisms (SNPs) at position $-1612 /-1617$ in women with pelvic organ prolapse and controls.

\begin{tabular}{llll}
\hline & \multicolumn{3}{c}{ SNP, no. of cases (\%) } \\
\cline { 2 - 4 } MMP-3 SNP & $\begin{array}{c}\text { Study group } \\
(\mathrm{n}=80)\end{array}$ & $\begin{array}{c}\text { Control group } \\
(\mathrm{n}=80)\end{array}$ & Total \\
\hline 5A/5A & $19(11.89)$ & $13(8.13)$ & $32(20)$ \\
5A/6A & $34(21.25)$ & $39(24.38)$ & $73(45.63)$ \\
6A/6A & $27(16.88)$ & $28(17.5)$ & $55(34.38)$ \\
Total & $80(50)$ & $80(50)$ & $160(100)$ \\
\hline
\end{tabular}

promoter SNPs. After qPCR and hybridization analysis, each subject was classified into three genotypes: $5 \mathrm{~A} / 5 \mathrm{~A}$, $5 \mathrm{~A} / 6 \mathrm{~A}$ and $6 \mathrm{~A} / 6 \mathrm{~A}$. The frequencies of the various $M M P-3$ gene promoter SNPs followed the Hardy-Weinberg Principle $(\mathrm{P}=0.21>0.05$ for the study group, $\mathrm{P}=0.9>0.05$ for the control group and $\mathrm{P}=0.4>0.05$ for all the participants. Further analysis data on checking Hardy-Weinberg equilibrium are not shown in favor of simplicity (29). Table $\mathrm{V}$ shows the frequencies of $5 \mathrm{~A} / 5 \mathrm{~A}, 5 \mathrm{~A} / 6 \mathrm{~A}$ and $6 \mathrm{~A} / 6 \mathrm{~A}$ alleles in women with and without POP. According to the result of the Chi-square test for independence with two degrees of freedom (Chi-square=1.49), there was no statistically significant difference between the two female groups and the three polymorphisms $(\mathrm{P}=0.48)$.

\section{Discussion}

The transcriptional activity of several MMP-encoding genes can be altered by various genetic polymorphisms in their promoter regions (30). A lower promoter activity of the $M M P-3$ gene is occasionally detrimental; for example, in patients suffering from cutaneous malignant melanoma (31). However, it may be favorable in other conditions, such as POP (24). In a recent study by Goncalves et al, it was shown that 'high plasma levels of MMP-3 were associated with lower plaque elastin content' (32). Therefore, a higher MMP-3 gene expression potentially decreases elastin concentrations in human body tissues, such as pelvic floor supporting structures (i.e., ligaments and fascia). Thus, a small transcriptional rate of the $M M P-3$ gene due to lower promoter activity may minimize the potentially harmful effect of MMP-3 on the aforementioned structures and reduce the risk for POP.

The findings of Skorupski et al (23) showed that, the $-1612 /-1617$ ins A SNP produces variants of the $M M P-3$ gene with clinical interest. Females with the $5 \mathrm{~A} / 5 \mathrm{~A}$ genotype have the greatest transcription level, while $6 \mathrm{~A} / 6 \mathrm{~A}$ women have the lowest transcription level. The abovementioned authors examined the possible combined effect of these SNPs on the female pelvic floor with the $1 \mathrm{G} / 1 \mathrm{G}, 1 \mathrm{G} / 2 \mathrm{G}$ and $2 \mathrm{G} / 2 \mathrm{G}$ polymorphisms at position -1607/-1608 upstream from the start of the $M M P-1$ gene transcription frame. It was found that, not only is the $M M P-1$ gene closely located to the $M M P-3$ gene (30), but MMP-3 can also activate proMMP-1, which increases the effect of MMP-1 on pelvic floor tissues (24). As a result, authors of that study concluded that 'it is possible that to become clinically evident the biological effect of the $2 \mathrm{G} / 2 \mathrm{G}$ MMP-1 variant has to be enhanced by the $5 \mathrm{~A} / 5 \mathrm{~A}$ or the $5 \mathrm{~A} / 6 \mathrm{~A}$ MMP-3 SNP' and that 'the 6A/6A variant seemed to play a protective role in POP only in conjunction with the $2 \mathrm{G} / 2 \mathrm{G}$ MMP-1 genotype'. However, the SNP distribution in that study was not in Hardy-Weinberg equilibrium.

The present study focused solely on MMP-3 SNPs in order to shed further light exclusively on the possible influence of the particular enzyme on the pelvic floor supporting tissues. The results, which were based on an SNP distribution in compliance with the Hardy-Weinberg equilibrium, showed no statistically significant difference in genotypes and allele frequencies, and of MMP-3 -1612/-1627 ins A polymorphism (rs 3025058). Our results are in agreement with those of Ferrari et al (21) and Skorupski et al (24). However, they do not provide sufficient evidence to recognize the above SNP of the $M M P-3$ gene promoter as a potential genetic risk factor for POP. Additionally, the study sample was relatively limited, and consequently our results need to be tested in comparison with more thorough findings obtained from larger groups.

In conclusion, the results of the present study, although based on a relatively small sample size, show that the SNPs of the $M M P-3$ gene promoter alone are not statistically associated with the risk of POP. Future studies based on larger samples may provide further power to the above results and shed more light on the potential genetic mechanisms involved in POP.

\section{References}

1. Ciangola CI, Capuano I, Perrone F and Franceschilli L: Epidemiology and Prevalence of Pelvic Floor Disorders. In: Pelvic Floor Disorders: Surgical Approach. Gaspari AL and Sileri P (eds). Springer Milan, Milano, pp9-15, 2014.

2. Dietz HP: Prolapse worsens with age, doesn't it? Aust N Z J Obstet Gynaecol 48: 587-591, 2008.

3. Neimark M: Genital Prolapse, Urogenital Atrophy, and Sexual Dysfunction. In: Pelvic Floor Dysfunction: A Multidisciplinary Approach. Davila GW, Ghoniem GM and Wexner SD (eds). Springer London, London, pp19-23, 2009.

4. Swift SE, Pound T and Dias JK: Case-control study of etiologic factors in the development of severe pelvic organ prolapse. Int Urogynecol J Pelvic Floor Dysfunct 12: 187-192, 2001.

5. Lien KC, Mooney B, DeLancey JOL and Ashton-Miller JA: Levator ani muscle stretch induced by simulated vaginal birth. Obstet Gynecol 103: 31-40, 2004.

6. Handa VL, Lockhart ME, Fielding JR, Bradley CS, Brubaker L, Cundiff GW, Ye W and Richter HE; Pelvic Floor Disorders Network: Racial differences in pelvic anatomy by magnetic resonance imaging. Obstet Gynecol 111: 914-920, 2008.

7. Jack GS, Nikolova G, Vilain E, Raz S and Rodríguez LV: Familial transmission of genitovaginal prolapse. Int Urogynecol J Pelvic Floor Dysfunct 17: 498-501, 2006.

8. Spence-Jones C, Kamm MA, Henry MM and Hudson CN: Bowel dysfunction: A pathogenic factor in uterovaginal prolapse and urinary stress incontinence. Br J Obstet Gynaecol 101: 147-152, 1994.

9. Sileri P, Franceschilli L, Cadeddu F, De Luca E, D'Ugo S, Tognoni V, Camperchioli I, Benavoli D, Di Lorenzo N, Gaspari AL, et al: Prevalence of defaecatory disorders in morbidly obese patients before and after bariatric surgery. J Gastrointest Surg 16: 62-66, discussion 66-67, 2012.

10. Liapis A, Bakas P, Pafiti A, Frangos-Plemenos M, Arnoyannaki N and Creatsas G: Changes of collagen type III in female patients with genuine stress incontinence and pelvic floor prolapse. Eur J Obstet Gynecol Reprod Biol 97: 76-79, 2001.

11. Xu P, Meng Q, Sun H, Yin Q, Yu H, Zhang Z, Cao M, Zhang Y and Li Y: Shrapnel nanoparticles loading docetaxel inhibit metastasis and growth of breast cancer. Biomaterials 64: 10-20, 2015. 
12. Fang J, Xiao L, Joo KI, Liu Y, Zhang C, Liu S, Conti PS, Li Z and Wang P: A potent immunotoxin targeting fibroblast activation protein for treatment of breast cancer in mice. Int J Cancer 138: 1013-1023, 2015.

13. Chu Y, Tang H, Guo Y, Guo J, Huang B, Fang F, Cai J and Wang Z: Adipose-derived mesenchymal stem cells promote cell proliferation and invasion of epithelial ovarian cancer. Exp Cell Res 337: 16-27, 2015.

14. Zhang Q, Guo Y, Dong R, Dai R and Zhou M: Suppressor of cytokine signaling 1-modulated metalloproteinases and tissue inhibitor of metalloproteinase in pulmonary fibrosis. Mol Med Rep 12: 3855-3861, 2015.

15. Curry TE Jr and Osteen KG: Cyclic changes in the matrix metalloproteinase system in the ovary and uterus. Biol Reprod 64 1285-1296, 2001.

16. Quinones S, Buttice G and Kurkinen M: Promoter elements in the transcriptional activation of the human stromelysin-1 gene by the inflammatory cytokine, interleukin 1 . Biochem J 302: 471-477, 1994.

17. Murphy G, Cockett MI, Stephens PE, Smith BJ and Docherty AJ: Stromelysin is an activator of procollagenase. A study with natural and recombinant enzymes. Biochem J 248: 265-268, 1987.

18. Tepliakov AT, Berezikova EN, Shilov SN, Grakova EV, Torim II, Efremov AV, Safronov ID, Pustovetova MG and Karpov RS Assessment of the role of matrix metalloproteinase-3 gene polymorphism in the development of chronic heart failure. Ter Arkh 87: 8-12, 2015 (In Russian).

19. Zhang C, Chen L and Gu Y: Polymorphisms of MMP-1 and MMP-3 and susceptibility to rheumatoid arthritis. A meta-analysis. Z Rheumatol 74: 258-262, 2015.

20. Davis FM, Rateri DL and Daugherty A: Abdominal aortic aneurysm: Novel mechanisms and therapies. Curr Opin Cardiol 30: 566-573, 2015.

21. Ferrari MM, Rossi G, Biondi ML, Viganò P, Dell'utri C and Meschia M: Type I collagen and matrix metalloproteinase 1 , 3 and 9 gene polymorphisms in the predisposition to pelvic organ prolapse. Arch Gynecol Obstet 285: 1581-1586, 2012.

22. Marín-García J (ed): Molecular Genetics of Coronary Artery Disease and Myocardial Infarction. In: Post-Genomic Cardiology. 2nd edition. Elsevier, Amsterdam, pp217-250, 2014.

23. Skorupski P, Miotła P, Jankiewicz K and Rechberger T: MMP-1 and MMP-3 gene encoding polymorphism and the risk of the development of pelvic organ prolapse and stress urinary incontinence. Ginekol Pol 81: 594-599, 2010 (In Polish)
24. Skorupski P, Jankiewicz K, Miotła P, Marczak M, Kulik-Rechberger B and Rechberger T: The polymorphisms of the MMP-1 and the MMP-3 genes and the risk of pelvic organ prolapse. Int Urogynecol J Pelvic Floor Dysfunct 24: 1033-1038, 2013.

25. Thiagamoorthy G, Zacchè M, Cardozo L, Naidu M, Giarenis I, Flint R, Srikrishna S and Robinson D: Digital assessment and quantification of pelvic organ prolapse (DPOP-Q): A randomised cross-over diagnostic agreement trial. Int Urogynecol J Pelvic Floor Dysfunct 27: 433-437, 2016.

26. Petrie A and Sabin C: Medical statistics at a glance. 3rd edition. John Wiley \& Sons, Inc., Hoboken, NJ, 2013.

27. Biancheri P, Brezski RJ, Di Sabatino A, Greenplate AR, Soring KL, Corazza GR, Kok KB, Rovedatti L, Vossenkämper A, Ahmad N, et al: Proteolytic cleavage and loss of function of biologic agents that neutralize tumor necrosis factor in the mucosa of patients with inflammatory bowel disease. Gastroenterology 149: 1564-1574.e3, 2015.

28. Dey S, Stalin S, Gupta A, Saha D, Kesh K and Swarnakar S: Matrix Metalloproteinase-3 gene promoter polymorphisms and their haplotypes are associated with gastric cancer risk in eastern Indian population. Mol Carcinog 51 (Suppl 1): E42-E53, 2012.

29. Waples RS: Testing for Hardy-Weinberg proportions: Have we lost the plot? J Hered 106: 1-19, 2015.

30. Vlaykova T, Kurzawski M, Tacheva T, Dimov D, Gulubova M, Yovchev Y, Chakarov S and Drozdzik M: Investigation of the role of MMP3 -1171insA polymorphism in cutaneous malignant melanoma - a preliminary study. Biotechnol Biotechnol Equip 28: 904-910, 2014.

31. Fröhlich E: Proteases in cutaneous malignant melanoma: Relevance as biomarker and therapeutic target. Cell Mol Life Sci 67: 3947-3960, 2010.

32. Goncalves I, Bengtsson E, Colhoun HM, Shore AC, Palombo C, Natali A, Edsfeldt A, Dunér P, Fredrikson GN, Björkbacka H, et al; SUMMIT Consortium: Elevated Plasma Levels of MMP-12 Are Associated With Atherosclerotic Burden and Symptomatic Cardiovascular Disease in Subjects With Type 2 Diabetes. Arterioscler Thromb Vasc Biol 35: 1723-1731, 2015. 